\title{
ABSORPTION OF INORGANIC, TRIVALENT AND HEXAVALENT CHROMIUM FOLLOWING ORAL AND INTRAJEJUNAL DOSES IN RATS
}

\author{
Hedvig FÉBEL ${ }^{*}$, B. SzEGEDI and Szilvia HuSZÁR \\ Research Institute of Animal Breeding and Nutrition, H-2053 Herceghalom, Hungary
}

(Received September 29, 2000; accepted February 8, 2001)

The intestinal absorption of trivalent and hexavalent chromium $(\mathrm{Cr})$ given orally (experiment I) or infused in the intestine (experiment II) was investigated in rats. The nonabsorbable form of chromium $\left({ }^{51} \mathrm{Cr}_{2} \mathrm{O}_{3}\right)$ and water-soluble and more absorbable $\mathrm{Na}_{2}{ }^{51} \mathrm{CrO}_{4}$ (the hexavalent form of $\mathrm{Cr}$ ) were compared. Total retention of chromium given orally ranged around 15 percent of the dose, regardless of the chromium compounds applied. The absorption rate of chromic oxide, which is considered a nonabsorbable compound, was 14.4 as a percentage of chromium intake. This result indicates that some loss of chromium has to be taken into account in metabolic trials made by the indicator method. In isolated rat intestine, from the injected $\mathrm{Cr} 2.5 \%$ of chromic oxide and $43.2 \%$ of sodium chromate were absorbed during an hour (experiment II). The absorbed chromium was transferred to the liver where the liver tissue retained $10.9 \%$ of chromic oxide and $51.1 \%$ of sodium chromate. Radioactivity of $\mathrm{v}$. cava caudalis following intestinal injection of $\mathrm{Na}_{2} \mathrm{CrO}_{4}$ was thirtyfold greater than after $\mathrm{Cr}_{2} \mathrm{O}_{3}$ dosing. This phenomenon can be explained by the lower blood clearance of chromate. Different absorption rate of chromate depending on the route of administration could be due to the fact that the hexavalent form given orally was reduced to $\mathrm{Cr}^{3+}$ in the acidic environment of the stomach. When $\mathrm{Na}_{2} \mathrm{CrO}_{4}$ was infused directly in the intestine of rats, such reduction could not occur. This means that the acidic gastric juice might play a role in inhibiting the intestinal absorption of $\mathrm{Na}_{2} \mathrm{CrO}_{4}$ when this compound is given orally.

Key words: Chromium, absorption, excretion, retention, rats

The use of chromium as a reference marker in absorption tests or balance studies is based on observations suggesting that this substance is absorbed poorly (Underwood, 1977). Nevertheless, it seems likely that some chromium is absorbed, since it is found in the tissues and urine of animals. The necessity of investigating chromium absorption is emphasised by the reported effects of trace quantities of chromium on cellular metabolism and enzyme activity.

The problem of intestinal absorption of chromium compounds and its dependence on the chemical structure are poorly understood. Some compounds

*Corresponding author; E-mail: hfebel@atk.hu; Fax: +36 (23) 319-133 
$\left(\mathrm{Cr}_{2} \mathrm{O}_{3}\right)$ are believed not to be absorbed at all, while others get into the different organs, as shown by observation of their biological effect and by the rise of tissue chromium levels after an oral administration. The purpose of our studies reported here was to measure the absorption, excretion and retention of two different chromium compounds dosed orally. The second part of the studies was designed to measure the absorption and distribution of intrajejunally injected chromium compounds. The final aim of these experiments was to compare the intestinal absorption of trivalent and hexavalent chromium given orally or infused into the intestine.

\section{Materials and methods}

Two experiments (I and II) were conducted with rats to investigate the absorption of $\mathrm{Cr}$. The experimental design was arranged according to the following table:

\begin{tabular}{|c|c|c|c|c|}
\hline & \multicolumn{2}{|c|}{ Experiment I } & \multicolumn{2}{|c|}{ Experiment II } \\
\hline & Group 1 & Group 2 & Group 1 & Group 2 \\
\hline Number of rats & 6 & 6 & 7 & 7 \\
\hline $\begin{array}{l}\text { Administered } \\
\text { compound }\end{array}$ & ${ }^{51} \mathrm{Cr}_{2} \mathrm{O}_{3}+\mathrm{Cr}_{2} \mathrm{O}_{3}$ & $\begin{array}{c}\mathrm{Na}_{2}{ }^{51} \mathrm{CrO}_{4}+ \\
\mathrm{Na}_{2} \mathrm{CrO}_{4}\end{array}$ & ${ }^{51} \mathrm{Cr}_{2} \mathrm{O}_{3}+\mathrm{Cr}_{2} \mathrm{O}_{3}$ & $\begin{array}{c}\mathrm{Na}_{2}{ }^{51} \mathrm{CrO}_{4}+ \\
\mathrm{Na}_{2} \mathrm{CrO}_{4}\end{array}$ \\
\hline $\begin{array}{l}\text { Administration } \\
\text { route }\end{array}$ & oral & oral & intrajejunal & intrajejunal \\
\hline
\end{tabular}

In experiment I, 6 male albino rats (WISTAR, SPF, HUMAN, Gödöllö, Hungary) per group, averaging $120 \mathrm{~g}$, were fed pelleted rat feed (CRLT/N, Charles River Hungary Ltd.). The animals were kept in individual wire-mesh metabolism cages with free access to water. The rats were divided into two groups according to the treatments. One group was given a nonabsorbable form of chromium $\left(\mathrm{Cr}_{2} \mathrm{O}_{3}\right)$ and the other group was treated with the water-soluble and more absorbable sodium chromate (hexavalent form of $\mathrm{Cr}$ ). Chromic oxide was chosen from the possible trivalent compounds because this substance is often used in metabolic experiments as a marker. The rats were fed $10 \mathrm{~g}$ of the diet daily. After receiving the diet during the 3-day experimental period, daily doses of $1500 \mathrm{kBq}$ of ${ }^{51} \mathrm{Cr}$ and $15 \mu \mathrm{mol}$ of $\mathrm{Cr}$ as $\mathrm{Cr}_{2} \mathrm{O}_{3}$ were administered to each rat orally in the first group and $1500 \mathrm{kBq}$ of ${ }^{51} \mathrm{Cr}$ and $15 \mu \mathrm{mol}$ of $\mathrm{Cr}$ as $\mathrm{Na}_{2} \mathrm{CrO}_{4}$ in the second group. The applied amount of chromium was the same as generally used in metabolic trials made by the indicator method. Faeces and urine were quantitatively collected for 3 days. The rats were treated according to the principles of laboratory animal care as promulgated by the Hungarian Committee on Animal Care. Faeces and urine were analysed for ${ }^{51} \mathrm{Cr}$ by a scintillation counter equipped with $\varnothing 40 \times 2.5 \mathrm{~mm} \mathrm{NaI(TI)} \mathrm{crystal.}$ 
In experiment II, 7 male albino rats of the same stock, averaging $250 \mathrm{~g}$ in weight, were used in each group. Absorption of chromic oxide (Cr III) and sodium chromate $(\mathrm{Cr} \mathrm{VI})$ was studied in isolated intestine of rat using radiochromium marker. The rats were fasted for $24 \mathrm{~h}$ prior to surgery to ensure an empty intestinal lumen. They were anaesthetised with an intraperitoneal injection of sodium pentobarbital. An abdominal incision was made and the small intestine was exposed.

Absorption was measured over a $15-\mathrm{cm}$ segment of jejunum. The two ligaments were placed on the same part of the jejunum. The intestinal solution was infused into the proximal end of the gut sac. The composition of perfusate was different. In the first group $15 \mu \mathrm{mol} \mathrm{Cr}$ and $1500 \mathrm{kBq}{ }^{51} \mathrm{Cr}$ as $\mathrm{Cr}_{2} \mathrm{O}_{3}$ and in the second group as $\mathrm{Na}_{2} \mathrm{CrO}_{4}$ were given. The injected $\mathrm{Cr}$ concentration corresponded to the doses applied in experiment I.

Following a single intestinal tracer dose of chromium the laparotomy incision was sutured. After $60 \mathrm{~min}$, blood samples were taken from the v. portae, v. hepatica and v. cava caudalis, then the rats were killed with sodium pentobarbital. The gut sac was removed and washed. The liver was also removed. Infusion fluid from the gut sac, liver and blood samples were analysed for ${ }^{51} \mathrm{Cr}$ by the same method as described earlier.

\section{Results}

\section{Experiment $I$}

For both trivalent chromium and chromate, the faeces was the predominant route of excretion (Table 1). However, rats that had been given chromate excreted smaller amount of chromium through the faeces. Faecal $\mathrm{Cr}$ excretion was lower in Group $2(36.89 \mu \mathrm{mol})$ than in the rats of Group $1(39.15 \mu \mathrm{mol})$. Thus, calculated $\mathrm{Cr}$ excretion was also lower, $80.66 \%$ vs. $85.58 \%$ of the dose. Total urinary $\mathrm{Cr}$ excretion of the first and second group was 0.29 and $0.99 \mu \mathrm{mol}$, respectively. Rats that had been given chromate (Group 2) had significantly higher urinary $\mathrm{Cr}$ as a percentage of the oral dose. No significant difference was found in the retention of chromium. From the total $\mathrm{Cr}$ excretion it was calculated that in case of $\mathrm{Cr}_{2} \mathrm{O}_{3} 13.78 \%$ and in rats fed chromate (Group 2) $17.16 \%$ of the $\mathrm{Cr}$ dose was retained.

\section{Experiment II}

The absorption of intrajejunally administered chromic oxide was much lower than that of chromate (Table 2). Because of the lower absorption smaller amount of chromium could be detected in the v. portae and in the liver. Chromium concentrations of the $\mathrm{v}$. portae and liver tissue were $2.87 \mathrm{nmol} / \mathrm{ml}$ and 40.2 nmol, respectively. 
Table 1

Excretion rate of orally administered chromium compounds (experiment I)

\begin{tabular}{|c|c|c|c|}
\hline & & Group 1 & Group 2 \\
\hline Number of rats & & 6 & 6 \\
\hline Administered compound & & ${ }^{51} \mathrm{Cr}_{2} \mathrm{O}_{3}+\mathrm{Cr}_{2} \mathrm{O}_{3}$ & $\mathrm{Na}_{2}{ }^{51} \mathrm{CrO}_{4}+\mathrm{Na}_{2} \mathrm{CrO}_{4}$ \\
\hline Cr intake & $\mu \mathrm{mol} /$ day & $0.138+15.109$ & $0.138+15.109$ \\
\hline Total Cr intake & $\mu \mathrm{mol}$ & 45.742 & 45.742 \\
\hline Activity & $\mathrm{kBq} /$ day & 1500 & 1500 \\
\hline Total activity & $\mathrm{MBq}$ & 4.5 & 4.5 \\
\hline \multirow[t]{2}{*}{$\mathrm{Cr}$ content of faeces } & $\mu \mathrm{mol}$ & $39.15 \pm 1.09$ & $36.89 \pm 2.27$ \\
\hline & $\%$ & $85.58 \pm 2.38$ & $80.66 \pm 4.96$ \\
\hline \multirow[t]{2}{*}{$\mathrm{Cr}$ content of urine } & $\mu \mathrm{mol}$ & $0.29 \pm 0.11$ & $0.99 * \pm 0.28$ \\
\hline & $\%$ & $0.64 \pm 0.23$ & $2.17 * \pm 0.60$ \\
\hline \multirow[t]{2}{*}{ Total Cr excretion } & $\mu \mathrm{mol}$ & $39.44 \pm 1.05$ & $37.89 \pm 2.07$ \\
\hline & $\%$ & $86.22 \pm 2.30$ & $82.83 \pm 4.53$ \\
\hline \multirow[t]{2}{*}{ Retention } & $\mu \mathrm{mol}$ & $6.30 \pm 1.05$ & $7.85 \pm 2.07$ \\
\hline & $\%$ & $13.78 \pm 2.30$ & $17.16 \pm 4.50$ \\
\hline
\end{tabular}

${ }^{*}$ Significant difference at $\mathrm{P}<0.05$

Table 2

Chromium absorption from the jejunum (experiment II)

\begin{tabular}{|c|c|c|c|}
\hline & & Group 1 & Group 2 \\
\hline Number of rats & & 7 & 7 \\
\hline Administered compound & & ${ }^{51} \mathrm{Cr}_{2} \mathrm{O}_{3}+\mathrm{Cr}_{2} \mathrm{O}_{3}$ & $\mathrm{Na}_{2}{ }^{51} \mathrm{CrO}_{4}+\mathrm{Na}_{2} \mathrm{CrO}_{4}$ \\
\hline Activity & $\mathrm{kBq}$ & 1500 & 1500 \\
\hline Intrajejunally injected $\mathrm{Cr}$ & $\mu \mathrm{mol}$ & 15 & 15 \\
\hline Cr retention in the jejunum & $\mu \mathrm{mol}$ & $14.63 \pm 0.04$ & $8.52 \pm 0.50$ \\
\hline Absorbed $\mathrm{Cr}$ & $\mu \mathrm{mol}$ & $0.37 \pm 0.04$ & $6.48 \pm 0.48$ \\
\hline $\mathrm{Cr}$ content of liver & nmol & $40.2 \pm 6.9$ & $3309.4 \pm 772.6$ \\
\hline Cr content of $\mathrm{v}$. portae & $\mathrm{nmol} / \mathrm{ml}$ & $2.87 \pm 0.60$ & $48.18 \pm 6.13$ \\
\hline $\mathrm{Cr}$ content of $\mathrm{v}$. hepatica & $\mathrm{nmol} / \mathrm{ml}$ & $2.57 \pm 0.65$ & $24.01 \pm 3.28$ \\
\hline Cr content of v. cava caudalis & $\mathrm{nmol} / \mathrm{ml}$ & $1.37 \pm 0.16$ & $40.29 \pm 6.81$ \\
\hline
\end{tabular}

The chromium concentration of the v. hepatica dropped to $2.57 \mathrm{nmol} / \mathrm{ml}$. The liver retained $10.9 \%$ of chromium from the blood. The v. cava caudalis contained less chromium $(1.37 \mathrm{nmol} / \mathrm{ml})$ than the v. hepatica. The difference detected between these two veins was $47 \%$. Intrajejunal administration of $\mathrm{Na}_{2} \mathrm{CrO}_{4}$ resulted in a significant absorption as indicated by the increased radioactivity of the v. portae. This rate was high because $6.48 \mu \mathrm{mol}$ chromium absorbed from the hexavalent form of chromium (more soluble than chromic oxide). An average of $43 \%$ of the infused chromium was absorbed. The large increase in $\mathrm{Cr}$ absorption after $\mathrm{Na}_{2} \mathrm{CrO}_{4}$ injection resulted in increased chromium content of the liver (3309 $\mathrm{nmol}$ of $\mathrm{Cr}$ ). The chromium level of the v. hepatica was 10-fold higher in 
the group with hexavalent chromium infusion than in the group given chromic oxide. After $\mathrm{Na}_{2} \mathrm{CrO}_{4}$ infusion, 1.7 times higher chromium content was measured in the v. cava caudalis than in the v. hepatica.

\section{Discussion}

In the first experiment the excretion rate and retention of trivalent and hexavalent chromium compounds were compared using ${ }^{51} \mathrm{Cr}$ isotope.

When either $\mathrm{Cr}_{2} \mathrm{O}_{3}$ or $\mathrm{Na}_{2} \mathrm{CrO}_{4}$ was administered orally to rats, most of the radioactivity could be recovered in the faeces. Absorption of orally given chromate was greater than that of the trivalent compound. Urinary $\mathrm{Cr}$ excretion was higher but could not follow the absorption rate, therefore retention was also higher. Chromium in the more soluble form absorbed better, and $81 \%$ of the chromium intake was excreted via the faeces. Total retention of chromium ranged around 15 percent of the dose, regardless of chromium compounds applied. The oral dose of chromate administered to rats resulted in an increased intestinal absorption of chromium, but this increment was much lower than expected. However, it was a great surprise that the absorption rate of chromic oxide, regarded as a nonabsorbable compound, amounted to 14.4 percent of the chromium intake.

Our results do not confirm previous observations (Whitby and Lang, 1960; Hansky and Connell, 1962; Gabriel et al., 1963) which indicated that the absorption of trivalent chromium is so small that it can be used as a convenient nonabsorbable marker for studies of intestinal absorption and excretion. Visek et al. (1953) reported intestinal absorption of less than $0.5 \%$ of an oral dose in rats. The proportion of an oral dose of chromic chloride absorbed by the rat appears to be independent of the amount given and of the nutritional status of the animals (Hopkins and Schwarz, 1964; Mertz et al., 1965). Donaldson and Barreras (1966) found that $0.1-1.2 \%$ of an oral dose appeared in the urine. A higher retention of $2-3 \%$ was calculated from results of total body counting of rats receiving $\mathrm{CrCl}_{3}$ by stomach tube (Mertz et al., 1965). The absorption of chromate is higher, with $2.1 \%$ of a dose appearing in the urine of man (Donaldson and Barreras, 1966) and 3-6\% in rats (MacKenzie et al., 1959). It can be assumed, however, that urinary chromium output underestimates the amount of chromium actually absorbed (Mertz, 1969).

It can be concluded that the first experiment measuring chromium excretion and retention in rats fed two different inorganic chromium compounds (1) failed to detect that trivalent chromium is poorly absorbed and (2) no such increment was observed after an oral dose of the more soluble sodium chromate.

In the second experiment the intestinal absorption of trivalent and hexavalent $\mathrm{Cr}$ in the rat jejunum was examined by the use of a gut sac procedure. 
In this manner four components of the absorptive pathway could be quantified: (1) Cr uptake from the intestinal lumen; (2) Cr transport into the blood stream (Cr concentration of v. portae); (3) Cr retention in the liver; (4) $\mathrm{Cr}$ retention in the tissues and excretion rate ( $\mathrm{Cr}$ concentration of $\mathrm{v}$. cava caudalis).

The mechanism responsible for the intestinal absorption of chromium is not well understood. It is unclear whether $\mathrm{Cr}$ is absorbed passively or with the aid of carrier proteins located in the intestinal mucosa. Mertz et al. (1965) reported that the absorption of trivalent $\mathrm{Cr}$ does not appear to be a saturable process, which suggests that it is absorbed by passive diffusion. Mertz and Roginski (1971) reported contrary evidence. They found that the percentage of trivalent $\mathrm{Cr}$ absorbed by everted gut sacs decreased as the $\mathrm{Cr}$ concentration increased in the incubation medium. This observed saturation effect suggests that carrier proteins are involved in $\mathrm{Cr}$ absorption. However, in the experiment of Dowling et al. (1989) it was concluded that inorganic, trivalent $\mathrm{Cr}$ is absorbed by the nonmediated process of passive diffusion in the small intestine of rats fed a Cr-adequate diet.

According to the results of this study, $2.5 \%$ of chromic oxide and $43.2 \%$ of sodium chromate were absorbed during an hour. The absorbed chromium was transferred to the liver where the liver tissue retained $10.9 \%$ of chromic oxide and $51.1 \%$ of sodium chromate. The chromium absorption result agrees well with that of MacKenzie et al. (1959) and Donaldson and Barreras (1966) who found that $\mathrm{Na}_{2} \mathrm{CrO}_{4}$ absorption was greater than that of $\mathrm{CrCl}_{3}$ and that blood radioactivity following intestinal infusion of $\mathrm{Na}_{2} \mathrm{CrO}_{4}$ was three- to fivefold greater than that observed after $\mathrm{CrCl}_{3}$ administration. In our study, the radioactivity of the v. cava caudalis following intestinal injection of $\mathrm{Na}_{2} \mathrm{CrO}_{4}$ was thirtyfold greater than the value after $\mathrm{Cr}_{2} \mathrm{O}_{3}$ dosing. These results could be explained by the lower blood clearance of chromate. The reasons can be the following: (i) The affinity of tissues for the trivalent form is greater than for the hexavalent. (ii) All chemical forms, except chromate, clear the blood quite rapidly. (iii) The accumulation of chromium from chromate may represent the chromium bound to red cells.

The experimental data revealed great differences in the absorption rate depending on the administration route of chromate. In rats given chromate orally nearly $20 \%$ of the dose could have entered the body from the intestine. In contrast to oral administration, more than $40 \%$ of the infused radioactivity was absorbed when $\mathrm{Na}_{2} \mathrm{CrO}_{4}$ was placed directly in the intestine. This observation is in agreement with previous experiments (Hansky and Connell, 1962; Donaldson and Barreras, 1966) where one fourth to one half of the administered radioactivity appeared to be absorbed when $\mathrm{Na}_{2} \mathrm{CrO}_{4}$ was placed directly in the intestine of humans or rats. This can be explained by the fact that the hexavalent form is easily reduced to $\mathrm{Cr}^{3+}$ in the acidic environment of the stomach. Thus, ingested chromium, regardless of its original form, is most likely to exist as $\mathrm{Cr}^{3+}$ by the time it reaches the small intestine. This means that the acidic gastric juice might play a role in inhibiting intestinal absorption of $\mathrm{Na}_{2} \mathrm{CrO}_{4}$ when this compound is 
given orally. This possibility was supported by the observations that patients with gastric achlorhydria absorbed significant amount of orally administered $\mathrm{Na}_{2} \mathrm{CrO}_{4}$ and treatment of $\mathrm{Na}_{2} \mathrm{CrO}_{4}$ with acidic gastric juice inhibited absorption of this compound when it was placed directly in the intestine.

\section{Conclusions}

The experimental results indicate that trivalent chromium in the form of $\mathrm{Cr}_{2} \mathrm{O}_{3}$ can absorb from the intestine. This observation does challenge the validity of using chromic oxide as a means of estimating digesta flow rate and digestibility of nutrients in metabolic trials.

Due to the fact that the hexavalent form is easily reduced to $\mathrm{Cr}^{3+}$ in the acidic environment of the stomach big differences can be detected in the absorption rate of chromate after oral administration and intrajejunal infusion.

\section{References}

Donaldson, R. M. and Barreras, R. F. (1966): Intestinal absorption of trace quantities of chromium. J. Lab. Clin. Med. 68, 484-493.

Dowling, H. J., Offenbacher, E. G. and Pi-Sunyer, F. X. (1989): Absorption of inorganic, trivalent chromium from the vascularly perfused rat small intestine. J. Nutr. 119, 1138-1145.

Gabriel, J., Solomon, N., Fierst, S. and Sass, M. (1963): Evaluation of chromic oxide marker in the absorption of fat. Am. J. Digest. Dis. 8, 280.

Hansky, J. and Connell, A. (1962): Measurement of gastrointestinal transit using radioactive chromium. Gut, 3, 187.

Hopkins, L. L. and Schwarz, K. (1964): Chromium(III) binding to serum proteins, specifically siderophilin. Biochim. Biophys. Acta 90, 484-491.

MacKenzie, R. D., Anwar, R. A., Byerrum, R. U. and Hoppert, C. A. (1959): Absorption and distribution of $\mathrm{Cr}^{51}$ in the albino rat. Arch. Biochem. Biophys. 79, 200-205.

Mertz, W. (1969): Chromium occurrence and function in biological systems. Phys. Rev. 49, 163-239.

Mertz, W. and Roginski, E. E. (1971): Chromium metabolism: the glucose tolerance factor. In: Mertz, W. and Cornatzer, W. E. (eds) Newer Elements in Nutrition. Dekker Press, New York, pp. 123-153.

Mertz, W., Roginski, E. E. and Reba, R. C. (1965): Biological activity and fate of intravenous chromium(III) in the rat. Am. J. Physiol. 209, 489-494.

Underwood, J. E. (1977): Trace Elements in Human and Animal Nutrition. Academic Press, New York, 260. pp.

Visek, W. J., Whitney, I. B., Kuhn, U. S. G. and Comar, C. L. (1953): Metabolism of $\mathrm{Cr}^{51}$ by animals as influenced by chemical state. Proc. Soc. Exptl. Biol. Med. 84, 610-615.

Whitby, L. and Lang, D. (1960): Experience with the chromic oxide method of fecal marking in metabolic balance investigations on humans. J. Clin. Invest. 39, 854. 